\title{
EFEK ANTIDIABETES TANAMAN OKRA (Abelmoschus esculentus)
}

\author{
Cahaya Carla Bangsawan ${ }^{1}$, Intanri Kurniati ${ }^{2}$
}

\author{
${ }^{1}$ Fakultas Kedokteran, Universitas Lampung \\ ${ }^{2}$ Bagian Patologi Klinik, Fakultas Kedokteran, Universitas Lampung
}

\begin{abstract}
Antidiabetic Effect of Okra (Abelmoschus esculentus). Diabetes mellitus is a degenerative disease characterized by blood sugar levels $\geq 200 \mathrm{mg} / \mathrm{dL}$, and fasting blood sugar levels $\geq 126 \mathrm{mg} / \mathrm{dL}$ or plasma blood sugar level 2 hours on an oral glucose tolerance test (OGTT) $\geq 200 \mathrm{mg} / \mathrm{dL}$ followed by symptoms of polydipsia, polyuria, and polyphagia. Based on 2018 Riskesdas data, the largest sufferers of diabetes mellitus are in the range of 55 - 64 years and $65-74$ years and are more dominated by women $(1.8 \%)$ than men $(1.2 \%)$ and are mostly found in urban areas $(1.9 \%)$ compared to rural areas $(1.0 \%)$. Long term use of drugs as diabetes therapy often causes several side effects that ultimately reduce the level of patient compliance in taking a drug. The okra (Abelmoschus esculentus) which belongs to Malvaceae family is a plant which is widespread in Indonesia and even in the world. This plant is widely consumed as an alternative therapy to treat diabetes mellitus by the public. This article review focuses on the influence of okra (Abelmoschus esculentus) as an anti-diabetic. Conclusion, the okra (Abelmoschus esculentus) can be an alternative therapy to control blood sugar levels in people with diabetes mellitus
\end{abstract}

Keywords: Diabetes Mellitus, Okra, Abelmoschus esculentus

Abstrak: Efek Antidiabetes Tanaman Okra (Abelmoschus esculentus). Diabetes melitus merupakan penyakit degeneratif yang ditandai dengan kadar gula darah yang melebihi batas normal dimana kadar gula darah sewaktu sama atau melebihi $200 \mathrm{mg} / \mathrm{dL}$, dan kadar gula darah puasa di atas atau sama dengan $126 \mathrm{mg} / \mathrm{dL}$ atau kadar gula darah plasma 2 jam pada Tes Toleransi Glukosa Oral (TTGO) $\geq 200 \mathrm{mg} / \mathrm{dL}$ diikuti dengan gejala polidipsia, poliuria, dan polifagia. Berdasarkan data Riskesdas 2018, penderita diabetes melitus terbesar berada pada rentang usia 55-64 tahun dan 65-74 tahun serta lebih didominasi oleh wanita (1.8\%) dibandingkan pria (1.2\%) dan banyak ditemui di daerah perkotaan $(1.9 \%)$ dibandingkan perdesaan (1.0\%). Penggunaan obat jangka panjang sebagai terapi diabetes sering kali menimbulkan beberapa efek samping yang akhirnya menurunkan tingkat kepatuhan pasien dalam meminum obat. Buah okra (Abelmoschus esculentus) termasuk dalam keluarga Malvaceae merupakan tanaman yang tersebar luas di Indonesia bahkan di dunia. Tanaman ini banyak dikonsumsi sebagai alternatif terapi untuk mengobati penyakit diabetes melitus oleh masyarakat. Review artikel ini tertuju pada pengaruh tanaman okra (Abelmoschus esculentus) sebagai anti diabetes. Simpulan, tanaman okra dapat menjadi terapi alternatif untuk mengontrol kadar gula darah pada penderita diabetes mellitus.

Kata kunci:Diabetes Melitus, Tanaman Okra, Abelmoschus esculentus

\section{PENDAHULUAN}

Pada kondisi saat ini, penyakit degeneratif telah masuk ke dalam sepuluh besar penyakit yang menyebabkan kematian terbanyak di Indonesia, salah satunya yaitu diabetes melitus (Depkes RI, 2008). Prevalensi serta jumlah kasus penderita diabetes semakin meningkat dalam beberapa dekade terakhir (WHO, 2016).

Pada tahun 2012, diabetes menyebabkan 1,5 juta kematian dan pada kadar gula darah yang lebih tinggi

dari standar maksimum akan menyebabkan tambahan 2,2 juta kematian serta akan terjadi peningkatan risiko penyakit kardiovaskular dan komplikasi lainnya (Kemenkes RI, 2014). Berdasarkan data Riskesdas 2018, penderita diabetes melitus terbesar berada pada rentang usia 55-64 tahun dan 65-74 tahun serta lebih didominasi oleh wanita $(1.8 \%)$ dibandingkan pria $(1.2 \%)$ dan banyak ditemui di daerah perkotaan (1.9\%) dibandingkan 
perdesaan (1.0\%). Diabetes merupakan penyakit kronis serius yang sering terjadi karena pankreas tidak mampu memproduksi cukup insulin (hormon yang mengatur gula darah atau glukosa), atau saat tubuh tidak mampu secara efektif menggunakan hormon insulin yang diproduksinya (Khairani, 2018).

Keluhan berupa poliuria, polidipsia, polifagia, serta penurunan berat badan secara drastis perlu diwaspadai sebagai gejala dari diabetes melitus (PERKENI, 2011).Namun, pada stadium awal keluhan - keluhan tersebut jarang disadari dalam waktu yang cukup lama hingga terjadi berbagai komplikasi (Ramadhan dan Marissa, 2015).

Selain gaya hidup, kepatuhan terapi farmakologi dengan obat - obatan menjadi salah satu upaya untuk mengendalikan kadar gula darah penderita diabetes melitus. Namun, obat - obatan ini tidak jarang menimbulkan efek samping sehingga membuat masyarakat mencari terapi alternatif lain.

Salah satu alternatif yang banyak digunakan oleh masyarakat luas untuk mengendalikan kadar gula darah ialah dengan tanaman okra.

Tanaman okra (Abelmoschus esculentus) merupakan tanaman herbal yang tinggi akan serat dan kandungan flavonoid sebagai antioksidan. Selain itu, tanaman okra juga mengandung $\alpha$ selulosa dan hemiselulosa yang termasuk ke dalam golongan serat atau dietary fiber yang memiliki efek antidiabetes (Uraku et al, 2011). Hal inilah yang menyebabkan banyaknya masyarakat sekarang yang mengonsumsi rebusan tanaman okra sebagai pengganti obat antidiabetes.

\section{METODE}

Review artikel ini menggunakan metode pengumpulan data sekunder yang sudah tertera pada sitasi dan daftar pustaka.

\section{HASIL DAN PEMBAHASAN}

\section{Menurut World}

Health

Organization (WHO), diabetes melitus ialah suatu penyakit berupa gangguan metabolisme kronis dengan multi etiologi dimana sering ditandai dengan kadar gula darah yang tinggi disertai dengan adanya gangguan metabolisme karbohidrat, lipid dan protein oleh karena insufisiensi fungsi insulin (Depkes RI, 2008).

Peningkatan kadar gula darah yang disebabkan oleh insufisiensi fungsi hormon insulin ini disebabkan oleh kerusakan pankreas yang salah satunya dapat dipicu oleh paparan senyawa radikal bebas yang merusak sel - sel pancreas (Ririn, 2012).

Selain itu, menurut Buraerah (2010) insufisiensi insulin dapat terjadi melalui 3 mekanisme, diantaranya (Buraerah, 2010):

a. Paparan eksogen (seperti virus, zat kimia, dlI) yang merusak sel - sel $\beta$ pankreas

b. Penurunan reseptor glukosa pada kelenjar pankreas

c. Kerusakan reseptor insulin di jaringan perifer

Berdasarkan klasifikasi Perkumpulan Endokrinologi Indonesia (PERKENI) tahun 2011, seorang individu dikatakan menderita diabetes melitus apabila kadar glukosa darah sewaktunya $\geq 200 \mathrm{mg} / \mathrm{dL}$ atau ditemukan gejala klasik diabetes melitus dengan kadar glukosa plasma puasa $\geq 126 \mathrm{mg} / \mathrm{dL}$ atau kadar gula darah plasma 2 jam pada tes toleransi kadar glukosa oral (TTGO) $\geq 200$ $\mathrm{mg} / \mathrm{dL}$ (PERKENI, 2011).

Menurut American Diabetes

Association (ADA), klasifikasi diabetes melitus berdasarkan etiologinya terdiri dari: (1). Diabetes Tipe 1 yang disebabkan oleh defisiensi insulin absolut oleh karena kerusakan sel $\beta$ pankreas dan diperoleh sejak lahir. (2). Diabetes tipe 2 yang disebabkan oleh pre dominan resistensi insulin dengan defisiensi insulin relatif sampai adanya dominan defek sekresi insulin dengan resistensi insulin dan biasanya disebabkan oleh pola hidup dan risiko keturunan. (3). Diabetes tipe lain yang disebabkan oleh defek genetik fungsi sel beta, defek genetik kerja insulin, serta penyakit eksokrin pankreas, dan lainnya. (4) Diabetes gestasional yang didapat selama masa kehamilan (PERKENI, 2011).

$\mathrm{Di}$ Indonesia sendiri banyak ditemukan diabetes melitus tipe 2. Hal ini disebabkan oleh multi faktor, diantaranya faktor lingkungan dan faktor keturunan. Faktor lingkungan meliputi adanya urbanisasi sehingga berubahnya gaya hidup sesorang yang awalnya 
mengonsumsi makanan yang sehat dan bergizi dari alam menjadi konsumsi makanan yang cepat saji. Menurut WHO, makanan cepat saji akan menimbulkan risiko tinggi untuk terjadinya obesitas yang menyebabkan seseorang memiliki risiko 4 kali lebih besar mengalami DM tipe 2 dibandingkan mereka dengan status gizi normal (WHO, 2016).Selain itu, penyakit DM tipe 2 juga dapat meningkatkan kejadian infeksi yang disebabkan oleh hiperglikemia di mana kadar gula darah tinggi dan penurunan fungsi fagosit. Infeksi yang sering terjadi pada penderita DM tipe 2 yaitu infeksi paru (Wijayanto et al, 2015).

Diabetes melitus merupakan penyakit kronik yang tidak menyebabkan kematian secara langsung, namun dapat menimbulkan komplikasi yang berakibat fatal apabila pengelolaannya tidak tepat (Ramadahan dan Marissa, 2015).

Tabel 1. Klasifikasi IImiah Tanaman Okra18

\begin{tabular}{|c|c|}
\hline \multicolumn{2}{|c|}{ Klasifikasi Ilmiah } \\
\hline Kingdom & Plantae \\
\hline Divisi & Magnoliophyta \\
\hline Kelas & Magnoliopsida \\
\hline Ordo & Malvales \\
\hline Famili & Abelmaceae \\
\hline Genus & $\begin{array}{c}\text { Abelmoschus } \\
\text { esculentus }\end{array}$ \\
\hline Spesies & melus ataund \\
\hline
\end{tabular}

Pada beberapa penelitian, telah dibuktikan bahwa ekstrak kulit atau biji okra dapat menstabilkan kadar gula darah, hiperlipidemia, memperbaiki kadar serum insulin dan morfologi hati, dan juga bisa menurunkan berat badan hewan uji coba dengan kondisi diabetes
Penatalaksanaan yang tidak tepat dapat mengakibatkan glukosa darah pasien tidak terkontrol serta menimbulkan komplikasi seperti nefropati diabetikum, ulkus diabetikum, neuropati diabetikum, stroke, kebutaan, dan menurunkan kualitas hidup penderita (Kocurek, 2009).

Tanaman okra (Abelmoschus esculentus) merupakan tanaman yang banyak digunakan sebagai alternatif pengobatan, salah satunya pada penyakit diabetes melitus. Bagian tananam okra yang paling banyak digunakan ialah buahnya. Buah okra sendiri memiliki sebutan lady's finger yang banyak tersebar di Nigeria, Afrika, Asia, Eropa Selatan dan Amerika (Riyanti et al, 2018).

Tabel 2. Kandungan Pada Buah Okra ${ }^{18}$

\begin{tabular}{|c|c|}
\hline Komposisi & Jumlah \\
\hline Air & $90,17 \mathrm{~g}$ \\
\hline Karbohidrat & $7,03 \mathrm{~g}$ \\
\hline Serat & $3,2 \mathrm{~g}$ \\
\hline Protein & $2 \mathrm{~g}$ \\
\hline Vitamin A & $13 \mathrm{~g}$ \\
\hline Vitamin C & $21.1 \mathrm{mg}$ \\
\hline Vitamin E & $0,36 \mathrm{mg}$ \\
\hline Magnesium & $57 \mathrm{mg}$ \\
\hline Seng & $0,6 \mathrm{mg}$ \\
\hline Kalsium & $0,81 \mathrm{mg}$ \\
\hline
\end{tabular}


Buah okra (Abelmoschus esculentus) juga mengandung senyawa metabolit sekunder diantaranya triterpenoid, fenolik, dan flavonoid. Flavonoid yang terkandung pada buah okra (Abelmoschus esculentus) merupakan kuersatin yang berfungsi sebagai agen hipoglikemik. Kuersetin juga merupakan komponen bioaktif yang memiliki fungsi antioksidan untuk menangkap radikal bebas(Roy, 204). Selain menangkap radikal bebas, kuersetin sebagai antioksidan juga dapat mencegah serta melindungi dari stress oksidatif serta menurunkan tekanan darah (Utami, 2018). Keadaan stress oksidatif ini dapat menyebabkan penyakit diabetes melitus yang apabila tidak dikontrol dengan baik dapat mengakibatkan komplikasi.

Aktivitas enzim dari alfaglukosidase inhibitor dan alfa-amilase inhibitor yang ditemukan pada ekstrak air buah okra berperan dalam proses penghambatan pemecahan karbohidrat menjadi monosakarida di usus. Hal inilah yang turut berperan untuk mengontrol kadar gula darah (Sabitha et al, 2011).

Pada penelitian Riyanti, et al (2018) dilakukan pengujian aktivitas inhibitor alfa-glukosidase secara in vitro menggunakan metode kalorimetri dimana acarbose (obat antidiabetes) dijadikan pembandingnya. Hasil penelitian tersebut menunjukan bahwa ekstrak air dan ekstrak etanol buah okra mampu menghambat enzim alfaglukosidase dengan nilai IC $_{50}$ berturut turut sebesar $32,607 \mu \mathrm{g} / \mathrm{ml}$, dan 57,502 $\mu \mathrm{g} / \mathrm{ml}$ serta nilai IC50 zat aktif akarbose adalah 10,95 $\mu \mathrm{g} / \mathrm{ml}$ (Riyanti et al, 2018).

Selain itu, bagian tanaman okra yag mengandung lebih banyak zat bioaktif adalah bijinya. Biji buah okra mengandung total polifenol dan total polisakarida masing - masing sejumlah $29.5 \%$ dan $14.8 \%$. Sedangkan, pada bagian kulit hanya mengandung total fenol sebesar $1.25 \%$ dan total polisakarida sebesar $43.1 \%$ (Fan et al, 2014).

Pada penelitian eksperimental yang dilakukan oleh Zaenab (2017) mengenai hubungan berbagai dosis infus buah okra dalam menurunkan kadar glukosa darah juga membuktikan bahwa semakin besar dosis yang diberikan maka akan semakin besar pula penurunan kadar gula darah (Zaenab, 2017).

Menurut Gasendo et al, infus (lendir) pada buah okra juga mengandung kedua zat hidrofilik dan hidrofobik yang memiliki potensi untuk mengikat lemak yang terdapat di dalam usus, sehingga dapat menurunkan kadar kolesterol total darah yang juga berhubungan dengan kadar glukosa darah (Gasendoet al, 2012).

\section{KESIMPULAN}

Ekstrak kulit, buah, maupun biji dari tanaman okra (Abelmoschus esculentus) dapat digunakan sebagai terapi alternative untuk menstabilkan kadar gula darah pada pasien diabetes melitus.

\section{DAFTAR PUSTAKA}

Buraerah, Hakim. (2010). Analisis faktor risiko diabetes melitus tipe 2 di PuskesmasTanrutedong, Sidenreg Rappan. Jurnal Ilmiah Nasional [diakses tanggal 28Agustus 2019]. Tersedia dari: http://lib.atmajaya.ac.id/default. spx?tabI

Depkes RI. 2008. Diabetes Mellitus ancaman umat manusia di dunia. Jakarta:Kemenkes RI.

Depkes RI. 2008. Pedoman pengendalian diabetes melitus dan penyakit metabolik. Direktorat PengendalianPenyakit Tidak Menular.

Fan S, Zhang $Y$, Sun $Q$, Yu L, Li M, Zheng $B$, Wu $X$, Yang $B$, Li $Y$, Huang $C$. 2014. Extract of okra lowers blood glucose and serum lipids in high fat dietinduced obese C57BL/6 mice. J Nutr Biochem. 25(7): hlm 702-709.

Gasendo, Cherie D., Julmarie Claire C. Pascua, dan Clair J. 2012. Cost effectiveanalysis of the extracted mucilagenous substance of Okra (HibiscusEsculentus) and corn starch as tablet binders. Journal of Pharmacy 3.

Kemenkes RI. 2014. Situasi dan analisis diabetes. Jakarta : Pusat Data

dan InformasiKementrian Kesehatan Republik Indonesia

Khairani. Hari Diabetes Sedunia Tahun 2018. 2018. Jakarta Selatan : 
Pusat Data danInformasi Kementrian Kesehatan RI

Kocurek, B. 2009. Promoting Medication adherence in older adults and the rest of us.Diabetes Spectr. $1 ; 22(2): 80-4$. [diakses tanggal

29 Agustus 2019]Tersediadari: http://spectrum.diabetesjournal org/cgi/doi/10.2337/

Mulyati, R.; Diah S. 2008. Ilmu etnobotani'hoinu'

abelmoschusesculentus:

pemanfaatan,prospek

pengembangannya di Sulawesi

Tenggara".Jakarta: Lembaga Ilmu Pengetahuan Indonesia.

PERKENI. 2011. Konsensus Pengelolaan dan Pencegahan Diabetes Melitus Tipe 2 diIndonesia. Jakarta; hlm $1-58$.

Perkeni. 2011. Pengolahan dan pencegahan diabetes militus tipe

2 di Indonesia.Perkumpulan Endikronologi Indonesia

Ramadhan, N., Marissa, N. 2015. Karakteristik penderita diabetes mellitus tipe 2 berdasarkan kadar HbA1c di Puskesmas Jayabaru Kota Banda Aceh. 2(2): hlm 50

Ramadhan, N., Marissa, N. 2015. Karakteristik penderita diabetes mellitus tipe 2 berdasarkan kadar HbA1c di Puskesmas Jayabaru Kota Banda Aceh. 2(2): hlm 49-56

Ririn, C. 2012. Pengaruh jumlah pasta tomat terhadap penurunan kadar gula darahpada mencit diabetes. Fakultas Teknologi Industri Pertanian: PASCAUniversitas Andalas [thesis]

Riyanti, S., Ratnawati, J., Aprilianti, S. 2018. Potensi buah okra (Abelmoschus esculentus (L.) Moench) sebagai inhibitor alfa glukosidase. 6(1), hlm 6-10

Roy, A. 2014. Functional properties of okra abelmoschus esculentus I.: Traditionalclaims and scientific evidences. Plant science today. 1(1): hlm 121-130

Sabitha V, Ramachandran S, Naveen KR, Panneerselvam K. 2011. Antidiabetic and antihyperlipidemic potential of Abelmoschus esculentus (L.) Moench instreptozotocin-induced diabetic rats. J Pharm Bioallied

Sci. 3(3): hlm 397-402.
Uraku, A.J.; Onuoha, S. C.; Offor, C.E.; Ogbanshi, M. E.; Ndidi, U. S.

2011. The effectsof abelmoschus esculentus fruits on ALP, AST and ALT of diabetic albino rats. International Journal of Science and Nature. 2(2): hlm 582-586

Utami, R.P. 2018. Kandungan gizi, total fenol, kuersetin, dan kapasitas antioksidantotal pada berbagai proses pemasakan okra (Abelmoschus esculentus L.); Bogor: IPB. [disertasi]

WHO. 2016. Fact Sheet of Diabetes.

Wijayanto, A., Burhan, E., Nawas, A., Rochsismandoko. 2015. Faktor terjadinyatuberkulosis paru pada pasien diabetes melitus tipe 2 . Journal RespiratoriIndonesia. 25(1): hlm 1-11. Tersedia dari: http://jurnalrespiratori .org/wp content/ uploads/2015/08/jri-jan 2015-35-1-1-11.pdf. [diakses tanggal 29Agustus 2019].

World Health Organization. 2016. Global Report on Diabetes. France:

World HealthOrganization. [Sitasi: 29 Agustus 2019]. Tersedia dari :http://www.who.int/diabetes/gl bal-report/en/.

Zaenab, S. 2017. Penggunaan berbagai dosis infus buah Okra (Abelmoschusesculentus) untuk penurunan kadar gula darah tikus putih (Rattusnorvegicus) hiperglikemia. SENASPRO : hlm 1229-39. 